\title{
IMPLEMENTING THE NEARLY ZERO-ENERGY BUILDINGS NOTION IN INDUSTRIAL FACILITIES
}

\author{
SIMONA MARINELLI ${ }^{1}$, RITA GAMBERINI ${ }^{1,2}$, BIANCA RIMINI $^{1}$ \& FRANCESCO NESI ${ }^{3}$ \\ ${ }^{1}$ Department of Sciences and Methods for Engineering (DISMI), University of Modena and Reggio Emilia, Italy \\ ${ }^{2}$ Interdepartmental Research Center for Industrial Research and Technology Transfer in the field of Integrated \\ Technologies for Sustainable Research, Efficient Energy Conversion, Energy Efficiency of Buildings, Lighting \\ and Home Automation (EN\&TECH), University of Modena and Reggio Emilia, Italy \\ ${ }^{3}$ Zero Energy and Passivhaus Institute for Research (ZEPHIR), Italy
}

\begin{abstract}
Buildings have a central role to play in the energy transition driven by the European Commission with the introduction of the nearly zero-energy buildings notion for both new constructions and existing building stocks. Despite the growing interest in improving the energy performance of residential as well as office buildings, a research gap is identified in the field of the renovation of industrial buildings and facilities in terms of energy efficiency. A lack is recognized in terms of analysing the improvement of the work environment in all the areas that are not used as offices. Common decarbonisation strategies are usually adopted, as the electrification of some processes, the replacement of obsolete machinery or the implementation of renewable energy sources. However, reaching the ambitious levels set by the Energy Performance of Buildings Directive which aims at nearly zero-energy buildings, remains a challenge. The present paper aims to analyse the main barriers that hamper the development of highly energy efficient and decarbonised buildings in the productive sector and the effective deep energy renovations of industrial facilities. Moreover, it intends to highlight alternative strategies and opportunities and to underline potential benefits.
\end{abstract}

Keywords: sustainable buildings, nearly zero-energy, industrial buildings, precast constructions, indoor environmental quality.

\section{INTRODUCTION}

One of the European's key strategies towards the transition to low-carbon energy systems to meeting global commitments to climate change mitigation, is the decarbonization of the building sector [1].

It is demonstrated that, with appropriate building design strategies focused on reliably achieving very low energy, the building sector can contribute its share to the $1.5^{\circ} \mathrm{C}$ goal, both for new-built and refurbishment of the existing building stock [2], [3].

In this context, the Energy Performance of Buildings Directive (EPBD) introduced the definition of nearly zero-energy building (nZEB) as a building with very high energy performance, where the nearly zero or very low amount of energy required should be extensively covered by renewable sources produced on-site or nearby [4].

According to the EPBD, it is required that all new buildings will be nZEB by the end of 2020. However, the main goal of the directive is to increase the renovation rate and move inefficient buildings onto a more sustainable path [5].

Despite being a challenging ambition influenced by many factors [6], in recent years a growing attention has been given to improving the energy performance of buildings, mainly focusing on the residential sector [7].

With regards to the non-residential sector, accounting for $25 \%$ of the total stock in Europe, the consideration has tended to focus on the most energy intensive building typologies [8], such as hospitals, hotels and restaurants [9], [10] and educational buildings [11], [12].

Industrial facilities, on the other hand, are seldom studied under an energy retrofit perspective [13], with surprising efforts focusing on indoor office environments [14], while 
a lack is recognized in terms of analysing the improvement of the work environment in all the areas that are not used as offices.

Industrial buildings are deeply investigated when used for other purposes, e.g., as housing [15] or mixed-uses [16], [17] or in case of seismic performance improvement [18].

Many attempts have been made in order to decarbonise the production processes and the manufacturing operations [19], [20], largely responsible for the environmental impacts of firms [21].

This trend has been largely promoted by the diffusion of Energy Management Systems (EnMSs) and the adoption of regulation and codes as the ISO 50001, aimed at making the productive activities of the industrial sector more efficient in the use of energy leading to the reduction of greenhouse gases emissions [22].

Small and medium-sized enterprises (SMEs) are normally excluded by EnMSs, although in the EU there are 22 million SMEs which represent $99 \%$ of all companies [23].

Even if absolute energy use per firm in SMEs (industrial and non-industrial), and nonenergy intense companies, is lower than in large, energy-intensive industrial companies, those of SMEs is a crucial sector for sustainable development. Crafts and small enterprises typically rely on their local roots and make an essential contribution to local development and social integration, by creating jobs and ensuring the transfer and continuous improvement of specific knowhow, unique traditions and historic and cultural heritage [24].

In this context, promoting the workers well-being and moving towards a human-centered organization model is a key factor for sustainable development [25]. It is largely demonstrated that workers who are directly exposed to an unacceptable working environment may have increased health symptoms and decreased productivity [26]-[30].

Based on this background and starting from the available literature, an overview on the main critical aspects related to the energy performance of industrial facility buildings are presented (Section 2), the main barriers and drivers related to the development of decarbonised buildings in the productive sector are investigated (Section 3) and feasible energy efficiency renovations measures are discussed (Section 4).

The overall aim is to underline potential benefits in improving the nZEB design strategies for existing industrial buildings both at the single and collective level.

\section{INDUSTRIAL FACILITIES: AN OVERVIEW}

The buildings of the tertiary sector are usually precast structures, typically built as an assembly of monolithic elements: main and secondary beams, square-cross section columns, concrete or sandwich panels as roof and wall elements, ribbon windows and modular windows skylights [31], [32].

From the energy performance and the workplaces comfort point of view, the critical issues affecting those kinds of structures are various. They usually need not only winter but also summer air conditioning in addition to artificial lighting. It is demonstrated that the carbon and energy footprint of typical prefabricated industrial buildings are mainly affected by the energy need for heating and cooling and for lighting [33].

The problem of air high temperatures inside industrial workplaces occurs particularly during hot sunny days, leading to a proved exposition of workers to thermal stress [34].

Among the different sources of solar heat gain, the heat gain through the roof is one of the predominant, especially for the single-storey industrial type buildings with metal roof, affected by the penetration of direct solar heat into the working indoor space, which needs to be cooled for improving working efficiency as well as thermal comfort of the workers [35], despite a significant increase in the cooling load. 
Therefore, the building envelope could deeply influence the working environment conditions as much as workstations, like manual and automatic welding stations, oven entrances, assembly stations near hot bath stations, identified as critical because source of high indoor temperature [36].

\section{ENERGY EFFICIENCY IN RENOVATION OF INDUSTRIAL BUILDINGS}

Industrial enterprises tend to focus their efforts on energy intensive processes, therefore the energy retrofitting of the productive buildings they occupy is a scarcely implemented strategy, hindered by several critical issues, despite there may be positive effects that could result from it.

\subsection{Barriers}

The critical issues could be organizational, technical, economic or regulatory (Table 1).

The main difficulties are the technical ones, mainly related to the thermal bridges across the layer of insulation resulting in paths of greater heat loss [37], caused by the junctions between precast panels and structure elements and the connectors that penetrate the insulation layer [38], [39].

Economic barriers have been recognized in relation to the cost of collecting the energy data or installing new energy-efficient equipment [23], [40].

When compared with the simple purchase of energy, those initial costs could not be recognized as a cost savings investment, resulting in a greater obstacle to small and mediumsized enterprises [41].

Table 1: Barriers affecting the energy retrofit of industrial buildings.

\begin{tabular}{lll}
\hline Barrier & & Source \\
\hline Technical & & \\
& Lack of data and information & {$[41]$} \\
& Ventilation air change rate uncertainty & {$[42],[43]$} \\
& Difficulty in evaluating indoor comfort & {$[40],[44]$} \\
& Plant layout modification & {$[40]$} \\
& Thermal bridges and air leakages & {$[37]-[39]$} \\
Economic & & \\
& Investment uncertainty & {$[23],[40]$} \\
Regulatory & Energy data requirement & {$[41]$} \\
& & \\
& Regulatory uncertainty & {$[45]$} \\
\hline
\end{tabular}

\subsection{Drivers}

The benefits deriving from industrial building renovations are various, e.g. the energy consumption reduction leading to cost savings, indoor climate enhancement, plant layout improvement [46].

The high energy performance allows not only to reduce management costs, but also to ameliorate indoor environmental quality (IEQ). Besides improving the conditions of life of workers, the implementation of the best IEQ helps in increasing the market value of the property and, above all, it represents a strong and clear message of the policies that the companies intend to propose on an ethical level [47]. 
Table 2: Summary of common energy savings measures adopted in industrial facilities.

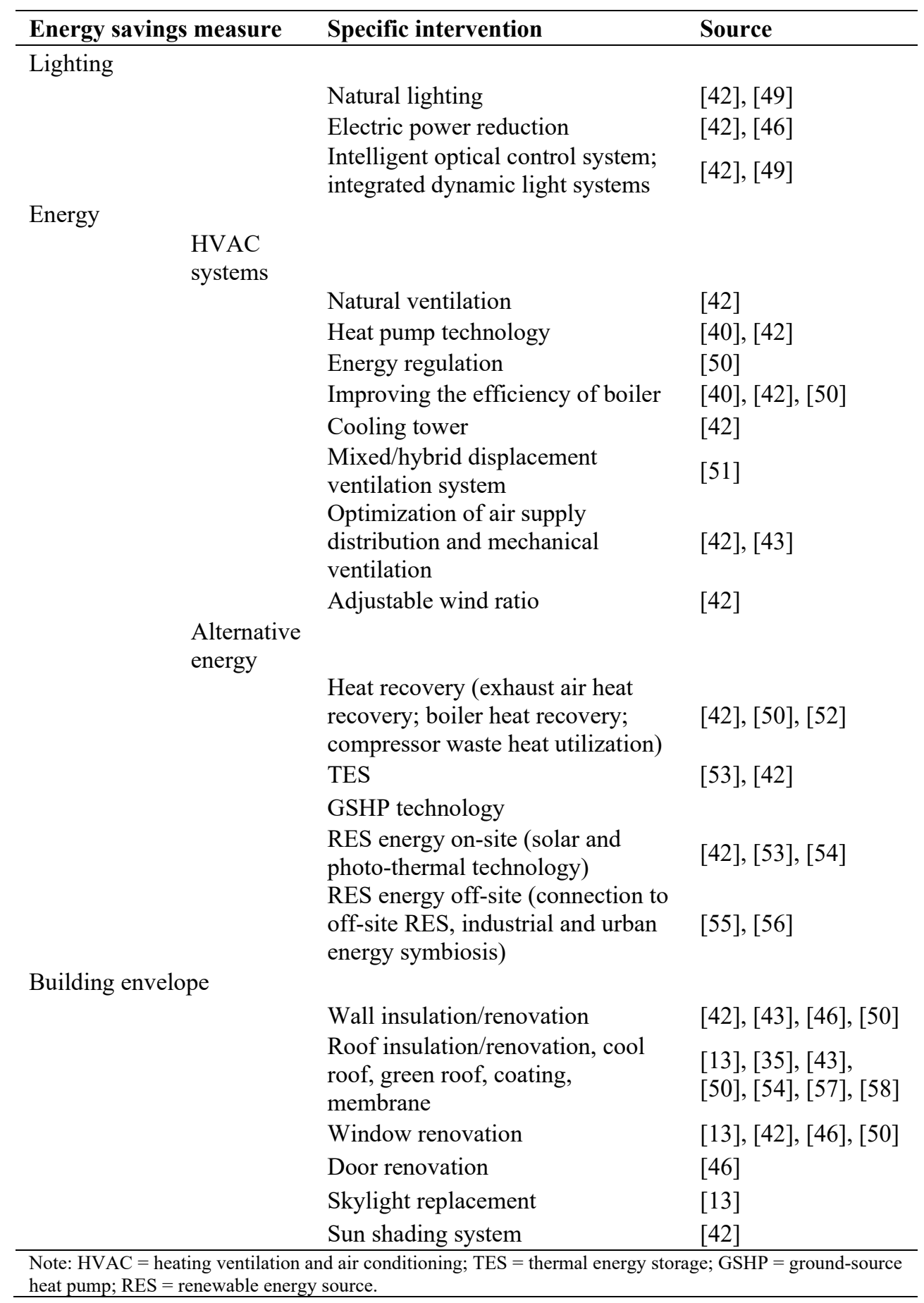


Moreover, such improvements may represent a useful means to build awareness, and involve employees in energy savings [48].

\section{ENERGY SAVINGS MEASURES IN INDUSTRIAL FACILITIES}

The available literature on the topic, highlights several measures that can be implemented, in order to reduce the energy consumption of industrial facilities.

These measures can be categorized in three common areas [48], as related to the lighting, to the energy systems that provide heating ventilation and air conditioning (HVAC) and to the building envelope (Table 2).

\subsection{Lighting}

Although representing generally a few percentage in the industrial energy consumption, lighting contributes significantly to electrical energy consumption [59] as well as to the increasing of internal heat gain.

So, even when lighting is a relatively small part of a plant's energy use, it may be possible to find considerable energy savings from improving natural lighting [49], using more efficient lighting systems as light emitting diode (LED) technologies, reducing electric power [46] or installing intelligent optical control system [42], considering the fact that not all areas of a building are occupied all of the time. Automatic controls and sensors can be deployed to match lighting provision to need.

Furthermore, the importance of industrial lighting can be appreciated both in terms of energy consumption, but also in terms of safety, due to the need to provide adequate visibility so that materials can be transformed into finished products without hazards for the operators executing the tasks [60].

Reducing the lighting levels where there is over lamping and meeting the standard recommendations for lighting levels according to purpose, helps to reduce electricity consumption and meet visual comfort levels.

\subsection{HVAC systems}

HVAC systems can cover a consistent share of the industrial energy consumption due to their primary role both being submitted to the production processes, but also in providing a comfortable environment to the operators.

They should be used to maximize comfort and health condition by controlling humidity, temperature and air quality, with the minimum input of energy.

There are various cost-effective opportunities for the energy saving, as heat pump technologies installation [40], [42], or improving the energy efficiency of existing equipment as boilers [40], [42], [50].

The mechanical ventilation also plays an important role for providing fresh air while recovering a big fraction of the ventilation heat otherwise lost by ventilation [42], [43], [51].

\subsection{Alternative energy}

According to the EBPD, the nearly zero or very low amount of energy required should be covered to a very significant extent by energy from renewable sources, produced on-site or nearby. Various supply-side renewable energy (RE) generation technologies are available for NZEBs, depending on the location of RE generation [61], [62]:

- demand-side, as ground-source heat pumps [42], [50], [52]. 
- $\quad$ on-site, where all the renewable energies are available on-site and are generated within the building footprint or within the boundary of the building site, as photovoltaic (PV) and solar technologies located on the roof or on adjacent buildings spaces [42], [53], [54].

- $\quad$ off-site, when the building uses off-site energy with the connection to grid purchasing energy generated by RES. The renewable sources can be provided from both the urban and the industrial context, as in the case of industrial and urban energy symbiosis [55], [56], [63].

\subsection{Building envelope}

Improving the building envelope is a primary concern to reach nZEB standards and indoor comfort [64], [65].

The most effective strategy of limiting heat loss (or gain) and reducing the energy need, is via the application of (additional) insulation to walls and roofs or the substitution of existing prefabricated panels with more performing components [42], [43], [46], [50].

The cooling load of the metal roof industrial buildings could be reduced with the help of paraffin-based phase changing material (PCM), decrementing the daily average indoor temperature by $5^{\circ} \mathrm{C}$ [35], or by applying innovative cool coatings (e.g., fluorocarbon, chromotropic and photocatalytic with self-cleaning functionalities, nano-composites, etc.) [57].

Green roofs is also a largely demonstrated technology able to reduce the thermal gain as well as the heat island effect, and to enhance the hydrology lost habitats [54].

\section{CONCLUSIONS}

Implementing the nearly zero-energy notion in industrial buildings is a promising strategy to pursue economic, environmental, and social sustainability goals. However, those buildings are still scarcely investigated.

Starting from the scientific literature available on the topic, this study analyses the key aspects of an effective deep energy renovation of the industrial facility buildings. It presents a general framework that includes an overview on the main critical factors and potential benefits deriving from the energy renovation, considering technical, economic and regulatory issues. Lastly, viable energy savings measures are investigated.

The aim is to support decision makers to requalify the industrial building stock, demonstrating that is a need linked not only to the energy transition, which leads both to economic savings and environmental impacts decrease. It is also a social issue, related to the design of comfortable and healthy industrial work environments and to the well-being of workers, a key concern especially in a European context characterized by small and mediumsized enterprises dealing with craft processes.

\section{REFERENCES}

[1] European Comission, Communication from the Commission to the European Parliament, the Council, the European Economic and Social Committee and the Committee of the Regions, $\operatorname{COM(2011)~112,~A~roadmap~for~moving~to~a~competitive~}$ low carbon economy in 2050, 2011. https:/eur-lex.europa.eu/LexUriServ/ LexUriServ.do?uri=COM:2011:0112:FIN:EN:PDF. Accessed on: 06 Aug. 2021. 
[2] Grove-Smith, J., Aydin, V., Feist, W., Schnieders, J. \& Thomas, S., Standards and policies for very high energy efficiency in the urban building sector towards reaching the $1.5^{\circ} \mathrm{C}$ target. Curr. Opin. Environ. Sustain., 30, pp. 103-114. 2018.

DOI: 10.1016/j.cosust.2018.04.006.

[3] Rogelj, J., Luderer, G., Pietzcker, R.C., Kriegler, E., Schaeffer, M., Krey, V. \& Riahi, K., Energy system transformations for limiting end-of-century warming to below $1.5^{\circ}$ C. Nat. Clim. Chang., 5, pp. 519-527, 2015. DOI: 10.1038/nclimate2572.

[4] Directive 2010/31/EU of the European Parliament and of the Council of 19 May 2010 on the energy performance of buildings (recast). Off. J. Eur. Union, 2010.

[5] Mariottini, F. \& Arcipowska, A., Nearly zero energy buildings definitions across Europe, 2015. https://www.bpie.eu/publication/nzeb-definitions-across-europe-2015. Accessed on: 6 Aug. 2021.

[6] Gonzalez-Caceres, A., Lassen, A.K. \& Nielsen, T.R., Barriers and challenges of the recommendation list of measures under the EPBD scheme: A critical review. Energy Build., 223, pp. 110065, 2020. DOI: 10.1016/j.enbuild.2020.110065.

[7] Wei, W. \& Skye, H.M., Residential net-zero energy buildings: Review and perspective. Renew. Sustain. Energy Rev., 142, pp. 110859, 2021.

DOI: $10.1016 /$ j.rser.2021.110859.

[8] Buildings Performance Institute Europe, BPIE Europe's Buildings Under the Microscope, ISBN 9789491143014, 2011.

[9] Smitt, S., Tolstorebrov, I., Gullo, P., Pardiñas, A. \& Hafner, A., Energy use and retrofitting potential of heat pumps in cold climate hotels. J. Clean. Prod., 298, 2021. DOI: 10.1016/j.jclepro.2021.126799.

[10] Becchio, C., Corgnati, S.P., Vio, M., Crespi, G., Prendin, L. \& Magagnini, M., HVAC solutions for energy retrofitted hotel in Mediterranean area. Energy Procedia, 133, pp. 145-157, 2017. DOI: 10.1016/j.egypro.2017.09.380.

[11] Attia, S., Shadmanfar, N. \& Ricci, F., Developing two benchmark models for nearly zero energy schools. Appl. Energy, 263, pp. 114614, 2020.

DOI: 10.1016/j.apenergy.2020.114614.

[12] Asdrubali, F., Ballarini, I., Corrado, V., Evangelisti, L., Grazieschi, G. \& Guattari, C., Energy and environmental payback times for an NZEB retrofit. Build. Environ., 147, pp. 461-472, 2019. DOI: 10.1016/j.buildenv.2018.10.047.

[13] Gourlis, G. \& Kovacic, I., A study on building performance analysis for energy retrofit of existing industrial facilities. Appl. Energy, 184, pp. 1389-1399, 2016.

DOI: 10.1016/j.apenergy.2016.03.104.

[14] Gangolells, M., Gaspar, K., Casals, M., Ferré-Bigorra, J., Forcada, N. \& Macarulla, M., Life-cycle environmental and cost-effective energy retrofitting solutions for office stock. Sustain. Cities Soc., 61, pp. 102319, 2020. DOI: 10.1016/j.scs.2020.102319.

[15] Valančius, K., Motuziene, V. \& Paulauskaite, S., Redeveloping industrial buildings for residential use: Energy and thermal comfort aspects. Energy Sustain. Dev., 29, pp. 38-46, 2015. DOI: 10.1016/j.esd.2015.09.004.

[16] Becchio, C., Ferrando, D.G., Fregonara, E., Milani, N., Quercia, C. \& Serra, V., The cost optimal methodology for evaluating the energy retrofit of an ex-industrial building in Turin. Energy Procedia, 78, pp. 1039-1044, 2015.

DOI: 10.1016/j.egypro.2015.11.057.

[17] Opher, T., Duhamel, M., Posen, I.D., Panesar, D.K., Brugmann, R., Roy, A., Zizzo, R., Sequeira, L., Anvari, A. \& MacLean, H.L., Life cycle GHG assessment of a building restoration: Case study of a heritage industrial building in Toronto, Canada. J. Clean. Prod., 279, pp. 123819, 2021. DOI: 10.1016/j.jclepro.2020.123819. 
[18] Soydan, C., Yüksel, E. \& İrtem, E., Seismic performance improvement of single-storey precast reinforced concrete industrial buildings in use. Soil Dyn. Earthq. Eng., 135, pp. 106167, 2020. DOI: 10.1016/j.soildyn.2020.106167.

[19] Henao, R., Sarache, W. \& Gómez, I., Lean manufacturing and sustainable performance: Trends and future challenges. J. Clean. Prod, 208, pp. 99-116, 2019. DOI: $10.1016 /$ j.jclepro.2018.10.116.

[20] Menghi, R., Papetti, A., Germani, M. \& Marconi, M., Energy efficiency of manufacturing systems: A review of energy assessment methods and tools. J. Clean. Prod., 240, pp. 118276, 2019. DOI: 10.1016/j.jclepro.2019.118276.

[21] Augusto de Oliveira, J., Lopes Silva, D.A., Devós Ganga, G.M., Filho, M.G., Ferreira, A.A., Esposto, K.F. \& Ometto, A.R., Cleaner production practices, motivators and performance in the Brazilian industrial companies. J. Clean. Prod., 231, pp. 359-369, 2019. DOI: $10.1016 /$ j.jclepro.2019.05.013.

[22] Sousa Lira, J.M., Salgado, E.G. \& Beijo, L.A., Which factors does the diffusion of ISO 50001 in different regions of the world is influenced? J. Clean. Prod., 226, pp. 759767, 2019. DOI: 10.1016/j.jclepro.2019.04.127.

[23] EEFIG Energy Efficiency - the first fuel for the EU Economy. ISBN 9788460660873, 2015.

[24] Report on the situation of craftsmanship in Europe, CR@FTSMAN PROJECT ES/09/LLP-LdV/TOI/149072, 2010.

[25] Papetti, A., Rossi, M., Menghi, R. \& Germani, M., Human-centered design for improving the workplace in the footwear sector. Procedia CIRP 2020, 91, pp. 295300, 2020. DOI: 10.1016/j.procir.2020.02.179.

[26] Kjellstrom, T. \& Crowe, J., Climate Change, Workplace Heat Exposure, and Occupational Health and Productivity in Central America, Vol. 17, ISBN $1077352117990,2011$.

[27] Nunfam, V.F., Adusei-Asante, K., Van Etten, E.J., Oosthuizen, J. \& Frimpong, K., Social impacts of occupational heat stress and adaptation strategies of workers: A narrative synthesis of the literature. Sci. Total Environ., 643, pp. 1542-1552, 2018. DOI: 10.1016/j.scitotenv.2018.06.255.

[28] Behrer, A.P. \& Park, J., Will we adapt? Temperature, labor and adaptation to climate change. Working paper, 2017.

[29] Nerbass, F.B., Pecoits-Filho, R., Clark, W.F., Sontrop, J.M., McIntyre, C.W. \& Moist, L., Occupational heat stress and kidney health: From farms to factories. Kidney Int. Reports, 2, pp. 998-1008, 2017. DOI: 10.1016/j.ekir.2017.08.012.

[30] Zander, K.K., Moss, S.A. \& Garnett, S.T., Drivers of self-reported heat stress in the Australian labour force. Environ. Res., 152, pp. 272-279, 2017.

DOI: 10.1016/j.envres.2016.10.029.

[31] Yesilyurt, A., Zulfikar, A.C. \& Tuzun, C., Seismic vulnerability assessment of precast RC industrial buildings in Turkey. Soil Dyn. Earthq. Eng., 141, pp. 106539, 2021. DOI: $10.1016 /$ j.soildyn.2020.106539.

[32] Savoia, M., Buratti, N. \& Vincenzi, L., Damage and collapses in industrial precast buildings after the 2012 Emilia earthquake. Eng. Struct., 137, pp. 162-180, 2017. DOI: 10.1016/j.engstruct.2017.01.059.

[33] Bonamente, E., Merico, M.C., Rinaldi, S., Pignatta, G., Pisello, A.L., Cotana, F. \& Nicolini, A., Environmental impact of industrial prefabricated buildings: Carbon and energy footprint analysis based on an LCA approach. Energy Procedia, 61, pp. 28412844, 2014. DOI: 10.1016/j.egypro.2014.12.319. 
[34] Kralikova, R., Sokolova, H. \& Wessely, E., Thermal environment evaluation according to indices in industrial workplaces. Procedia Eng., 69, pp. 158-167, 2014. DOI: 10.1016/j.proeng.2014.02.216.

[35] Boobalakrishnan, P., Manoj Kumar, P., Balaji, G., Jenaris, D.S., Kaarthik, S., Jaya Prakash Babu, M. \& Karthhik, K., Thermal management of metal roof building using phase change material (PCM). Mater. Today Proc., 2021.

DOI: 10.1016/j.matpr.2021.05.012.

[36] Morgado, M., Talaia, M. \& Teixeira, L., A new simplified model for evaluating thermal environment and thermal sensation: An approach to avoid occupational disorders. Int. J. Ind. Ergon., 60, pp. 3-13, 2017. DOI: 10.1016/j.ergon.2015.11.001.

[37] O'Hegarty, R., Reilly, A., West, R. \& Kinnane, O., Thermal investigation of thin precast concrete sandwich panels. J. Build. Eng., 27, pp. 100937, 2020.

DOI: $10.1016 /$ j.jobe.2019.100937.

[38] Shin, D.H. \& Kim, H.J., Composite effects of shear connectors used for lightweightfoamed-concrete sandwich wall panels. J. Build. Eng., 29, pp. 101108, 2020.

DOI: $10.1016 /$ j.jobe.2019.101108.

[39] Choi, K.B., Choi, W.C., Feo, L., Jang, S.J. \& Yun, H., Do In-plane shear behavior of insulated precast concrete sandwich panels reinforced with corrugated GFRP shear connectors. Compos. Part B Eng., 79, pp. 419-429, 2015.

DOI: 10.1016/j.compositesb.2015.04.056.

[40] Chinese, D., Nardin, G. \& Saro, O., Multi-criteria analysis for the selection of space heating systems in an industrial building. Energy, 36, pp. 556-565, 2011.

DOI: $10.1016 /$ j.energy.2010.10.005.

[41] Kim, H.Y. \& Kang, H.J., A study on development of a cost optimal and energy saving building model: Focused on industrial building. Energies, 9.

DOI: $10.3390 /$ en9030181.

[42] Wang, Q., Hu, Y.J., Hao, J., Lv, N., Li, T.Y. \& Tang, B.J., Exploring the influences of green industrial building on the energy consumption of industrial enterprises: A case study of Chinese cigarette manufactures. J. Clean. Prod., 231, pp. 370-385, 2019. DOI: 10.1016/j.jclepro.2019.05.136.

[43] Ahmed, T., Fung, A.S. \& Kumar, R., Energy benchmarking and ventilation related energy saving potentials for SMEs in Greater Toronto Area. J. Clean. Prod., 246, pp. 118961, 2020. DOI: 10.1016/j.jclepro.2019.118961.

[44] Wang, Y., Gao, J., Xing, X., Liu, Y. \& Meng, X., Measurement and evaluation of indoor thermal environment in a naturally ventilated industrial building with high temperature heat sources. Build. Environ., 96, pp. 35-45, 2016.

DOI: 10.1016/j.buildenv.2015.11.014.

[45] Malinauskaite, J., Jouhara, H., Ahmad, L., Milani, M., Montorsi, L. \& Venturelli, M., Energy efficiency in industry: EU and national policies in Italy and the UK. Energy, 172, pp. 255-269, 2019. DOI: 10.1016/j.energy.2019.01.130.

[46] Simson, R., Fadejev, J., Kurnitski, J., Kesti, J. \& Lautso, P., Assessment of retrofit measures for industrial halls: Energy efficiency and renovation budget estimation. Proceedings of the Energy Procedia, 2016.

[47] SMA solar factory proves its zero carbon green credentials. Renew. Energy Focus, 14, pp. 8, 2016. DOI: 10.1016/S1755-0084(13)70062-0.

[48] Fawkes, S., Oung, K. \& Thorpe, D., Best Practices and Case Studies for Industrial Energy Efficiency Improvement, ISBN 9788793130814, 2016. 
[49] Katunský, D., Dolníková, E. \& Doroudiani, S., Integrated lighting efficiency analysis in large industrial buildings to enhance indoor environmental quality. Buildings, 7, pp. 47, 2017. DOI: 10.3390/buildings7020047.

[50] Dongellini, M., Marinosci, C. \& Morini, G.L., Energy audit of an industrial site : A case study. Energy Procedia, 45, pp. 424-433, 2014. DOI: 10.1016/j.egypro.2014.01.046.

[51] Caputo, A.C. \& Pelagagge, P.M., Upgrading mixed ventilation systems in industrial conditioning. Appl. Therm. Eng., 29, pp. 3204-3211, 2009.

DOI: 10.1016/j.applthermaleng.2009.04.025.

[52] Hasanuzzaman, M., Rahim, N.A., Hosenuzzaman, M., Saidur, R., Mahbubul, I.M. \& Rashid, M.M., Energy savings in the combustion based process heating in industrial sector. Renew. Sustain. Energy Rev., 16, pp. 4527-4536, 2012.

DOI: 10.1016/j.rser.2012.05.027.

[53] Arteconi, A., Ciarrocchi, E., Pan, Q., Carducci, F., Comodi, G., Polonara, F. \& Wang, R., Thermal energy storage coupled with PV panels for demand side management of industrial building cooling loads. Appl. Energy, 185, pp. 1984-1993, 2017.

DOI: 10.1016/j.apenergy.2016.01.025.

[54] Catalbas, M.C., Kocak, B. \& Yenipınar, B., Analysis of photovoltaic-green roofs in OSTIM industrial zone. Int. J. Hydrogen Energy, 46, pp. 14844-14856, 2021.

DOI: 10.1016/j.ijhydene.2021.01.205.

[55] Marinelli, S., Butturi, M.A., Rimini, B., Gamberini, R. \& Marinello, S., Evaluating the environmental benefit of energy symbiosis networks in eco-industrial parks. IFACPapersOnLine, 53, pp. 13082-13087, 2020. DOI: 10.1016/j.ifacol.2020.12.2260.

[56] Butturi, M.A. \& Gamberini, R., Urban-industrial symbiosis to support sustainable energy transition. Int. J. Energy Prod. Manag., 5, pp. 355-366, 2020.

DOI: 10.2495/EQ-V5-N4-355-366.

[57] Mastrapostoli, E., Karlessi, T., Pantazaras, A., Kolokotsa, D., Gobakis, K. \& Santamouris, M., On the cooling potential of cool roofs in cold climates: Use of cool fluorocarbon coatings to enhance the optical properties and the energy performance of industrial buildings. Energy Build., 69, pp. 417-425, 2014.

DOI: 10.1016/j.enbuild.2013.10.024.

[58] Tian, G., Fan, Y., Wang, H., Zheng, H., Gao, M., Liu, J. \& Liu, C., Studies on the thermal optical properties and solar heat gain of thin membrane structure industrial building. Sol. Energy, 213, pp. 81-90, 2021. DOI: 10.1016/j.solener.2020.10.083.

[59] Worrell, E., Managing your energy: An ENERGY STAR ${ }^{\circledR}$ guide for identifying energy savings in manufacturing plants. Environ. Prot., 2010.

[60] Trianni, A., Cagno, E. \& De Donatis, A., A framework to characterize energy efficiency measures. Appl. Energy, 118, pp. 207-220, 2014.

DOI: $10.1016 /$ j.apenergy.2013.12.042.

[61] Pless, S. \& Torcellini, P., Net-zero energy buildings: A classification system based on renewable energy supply options, 2010. DOI: 10.2172/983417. https://www.osti.gov/ servlets/purl/983417. Accessed on: 6 Aug 2021.

[62] Feng, W., Zhang, Q., Ji, H., Wang, R., Zhou, N., Ye, Q., Hao, B., Li, Y., Luo, D. \& Lau, S.S.Y., A review of net zero energy buildings in hot and humid climates: Experience learned from 34 case study buildings. Renew. Sustain. Energy Rev., 114, pp. 109303, 2019. DOI: 10.1016/j.rser.2019.109303.

[63] Neves, A., Godina, R., Azevedo, S.G. \& Matias, J.C.O., Carbon dioxide recovery through industrial and urban symbiosis. ICITM 2020, 9th Int. Conf. Ind. Technol. Manag., pp. 171-175, 2020. DOI: 10.1109/ICITM48982.2020.9080405. 
[64] Albatayneh, A., Optimising the parameters of a building envelope in the east mediterranean Saharan, cool climate zone. Buildings, 11, pp. 1-23, 2021. DOI: $10.3390 /$ buildings11020043.

[65] Woods, T., Improving the building envelope to meet the challenges of new research and regulation. Therm. Perform. Exter. Envel. Whole Build., 2007. 